\title{
Article
}

\section{Information Oriented Problems in Newly Established Forest Management Systems - A case study in the river basin of the Yoshino River (Miyoshi) -}

\author{
Shigeki Yamada* and Naoto Matsumura*
}

\begin{abstract}
The profitability of forest management has been declining due to stagnating domestic timber prices and increasing management cost. With a waning in enthusiasm on the part of the forest owners, forest management is now in a state which is less than desirable. With this, there is no supply system which corresponds to the maturing of forest resources. In the river basin forest management system, it is necessary to constitute a system encompassing production, processing and distribution, from upstream to downstream. For this, it is vital that comprehensive information related to forests and forestry be systemized and a networked information system in a management unit be established. Such a network should provide the following functions

1) information exchange

2) collection of information for marketing

3) inter-connection with various industries

4) efficient management.

In this paper, a sample system is proposed for the study site and related problems are discussed.
\end{abstract}

Keyword: information oriented, forest information system, river basin forest management system

\section{INTRODUCTION}

In March 1991, referring to a report issued by the Forest Administration Council in 1990, the Forest Agency established a new forest policy, the River Basin Forest Management System. The purposes of this new policy were 1) improvement of diverse forest as sources of green and water, 2) improvement of the lumber production, processing and distribution system toward achieving an enhanced awareness and increased sales of domestic lumber.

In 1991, the Forest Law was revised toward improving forest planning systems and it has now become necessary to establish a new forest management system connecting these forest planning systems.

The economical and social backgrounds of this policy are as follows :

* Forest Management Laboratory, Shikoku Research Center, Forestry and Forest Products Research Institute, 915 Asakura-Tei, Kochi 780 Japan
1) Domestic forest resources, especially those planted during the post-war period, are maturing rapidly.

2) A lumber processing and distribution system suited to imported timber has been established.

3) The shortage in and the rapid aging of the forestry work force is becoming more pronounced.

4) The demands on forests by the general public is diversifying.

5) Due to these changes, forest management has also changed.

6) Improvement in national forest management efficiency has progressed.

To achieve the two purposes described above, the Forest Agency started a new project to promote activation of forestry and upstream areas from 1992. Through this policy, some progress has been made.

As noted above, the new policy was introduced in order to properly control forest resources and to maintain and develop upstream villages. In this paper, we discuss the necessities of the Forest Information System (F.I.S.) for the establishment of a river basin forest management sys- 
tem together with key points for that system by investigating movements in the Miyoshi region, Tokushima Prefecture, as a case study site.

\section{NECESSITY OF A FOREST INFORMATION SYSTEM}

In the river basin forest management system, the river basin area as a whole becomes the direct object of the forest policy. Taking the river basin as a unit, and with the consensus of people concerned, timber production, processing and distribution are streamlined. This makes it possible to formulate a plan wherein the structure of the downstream area becomes the lumber production, processing, distribution and consumption site linked with the situation of the forest resources in the upstream areas (MochIDA 1994). Specifically, it is systemization from production to consumption linking the forest resources in the upstream areas to the consumer market in the downstream areas (KAWAMURA 1995).

Except for several famous timber producing area such as Yoshino in Nara Prefecture, many timber producing areas are now facing serious problems in producing and selling their growing forest resources. A high percentage of the forest resources in these areas is sugi, which faces strong competition from imported timber such as western hemlock, for example. To overcome this competition, it is necessary to make every effort to cut production costs throughout the entire series of processes. From the standpoint of marketing strategies especially, it is vital that manufactured goods be supplied in the most appropriate manner. For example, the sawmills must constantly maintain the quality of their product and supply them in a timely manner while also fully complying with the prevailing demands. In order to decide the types and quantities of their products it is, therefore, necessary for the sawmills to obtain accurate information related to supply and demand as soon as possible. With this, strictly stockpile control is also vital. Several papers have reported such information oriented movements in the forest products industry (ANDO 1986, 1991; KATO 1991).

From the forest management and $\log$ production aspect, however, it is necessary to constitute a networked information system (AMANO 1986). To fully demonstrate a forest's multiple functions and to ensure forest conservation, it is vital that the present situation of the forests be determined in order to provide effective management, weeding and thinning, etc. However, many forest owners gave up due to a shortage of forest workers. Certain forestry enterprises such as forest owners' cooperatives have made some attempts wherein intentional cutting, cooperation in management practice, efficient operation of high performance forest machinery, distribution of the labor force were practiced by employing a forest information system (KATO 1994).

As stated, to establish a river basin forest management system, it is necessary to constitute a system of forest management and domestic timber supply system encompasses production, processing and distribution from upstream to downstream. For this, it is also vital a wide range of information related to forests and forestry be utilized synthetically. For this, a networked information system would be required.

\section{OUTLINE OF FORESTS AND FORESTRY IN THE MIYOSHI REGION}

The basin area lies within the north-western part of Tokushima Prefecture (see Fig. 1) and contains five towns - Mino, Miyoshi, Ikawa, Ikeda, Yamashiro, and two villages - Higashi-iyayama and Nishi-iyayama. The population of this area is about 58,000, although depopulation has continued here. In 1990, there were 18,646 households of which 7,445 (40\%) owned forest land. As there are many scenic areas in the region, tertiary industry was comparatively high at about $40 \%$ in the population ratio, or over $60 \%$ in the output. However, the importance of primary industry was not high, its percentage of the yield being only $6 \%$.

The following section provides an outline of forest and forestry using the data of the 1990 Census of Forestry and the Report of Fundamental Plans published in 1992.

The forest area occupies $72,313 \mathrm{ha}(86 \%)$. of this, $9,565 \mathrm{ha}(11 \%)$ is national forest and $62,743 \mathrm{ha}(89 \%)$ is private forest. The total stand volume is about $8,000,000 \mathrm{~m}^{3}$ with $90 \%$ of that volume being in private forest. In private forest, the ratio of artificial forest was $63 \%$, being relatively high to that of national forest $(42 \%)$. The plantation forests mainly consist of sugi (71\%) and hinoki (20\%). In distribution of age class, about $90 \%$ were under the VII age

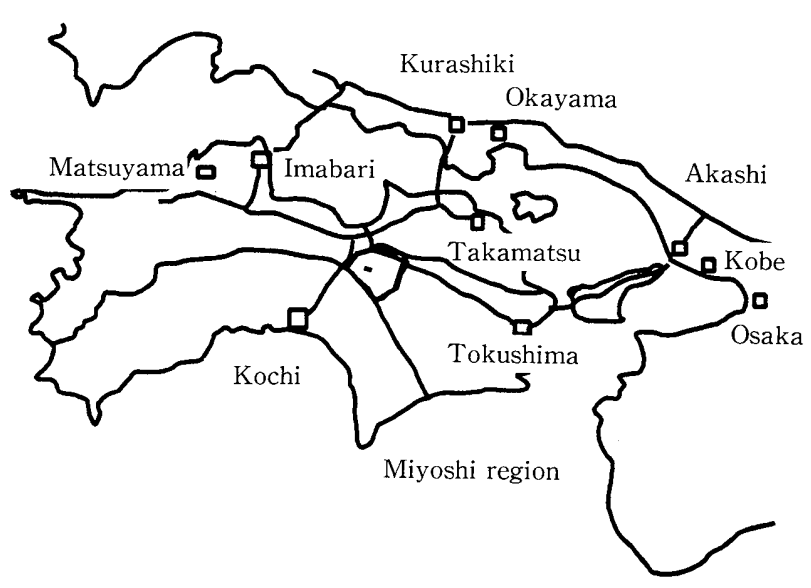

Fig. 1 Miyoshi region 
class.

The scale of household-owned and operated forest is generally small with an average area of 7.4 ha. However, $82 \%$ of these people own and operate areas of less than 5 ha. There are 26 large scale owners of over 100 hectares, although their activities provide no great influence upon the forestry in this region. The area owned by absentee land owners was $9,472 \mathrm{ha}(15 \%)$. The farm household ratio was $71 \%$ and the remainder non-farm households. The main source of income for these people was regular work such as office work etc, with $44 \%$ so engaged. Only $0.9 \%$ of the total households are engaged in self-employed forestry.

Table 1 illustrates the activities of forest owner households according to the type of work in which they were engaged for their own forest in 1980 and 1990. It is seen that the percentages of households carrying out afforestation declined in every town and village. Overall, the percentage had fallen 5 points, almost $50 \%$ of that of 1980 . The same is true of tending activities where in almost every town and village, the percentage had largely declined. Regarding thinning, circumstances are somewhat different and the ratios of households carrying out thinning showed a slight rise. In the Miyoshi region, therefore, it is seen that the forest owners were motivated only little in afforestation. However, in the face of the maturing of the forest resources and an increasing necessity to tend and thin, they made certain efforts in such activities but, perhaps due to the shortage of forest workers, were unable to adequately carry out those activities.

In 1990, the total log production for the area had increased to $107,000 \mathrm{~m}^{3}$ from the $80,000 \mathrm{~m}^{3}$ of 1972 . This increase was mainly observed in the private forest which at $98,000 \mathrm{~m}^{3}$, provided $91 \%$ of the production volume.

In 1990 , the plantation area was 169 hectares, being only $25 \%$ of that of 1975 . The recent trend is, therefore, a decrease in reforestation. In 1972, the reforestation area was 81 hectares which fell to a mere 19 hectares in 1990 .

In 1988, there were 77 logging contractors including eight forest owners ' cooperatives. In their production scale, many logging enterprises were marginal producers with an annual production less than $700-800 \mathrm{~m}^{3}$. However, the cooperative in Yamashiro is relatively active. Its production volume was about $3,400 \mathrm{~m}^{3}$ which represented $58 \%$ of all the timber produced by the forest owners' cooperatives. Yamashiro also has a small timber processing plant so this cooperative should be one of the core subjects in the region.

There is no market dealing with sawn timber, but there is one log market able to handle $42,000 \mathrm{~m}^{3}$ per year. However, due to narrow space, although the production volume in the region is rising, the total growth of its handling volume remains stagnant. In 1990, there were 29 sawmills in the region with a total log handling volume of $68,000 \mathrm{~m}^{3}$. In terms of $\log$ processed by these plants, 25 handled domestic logs.

As previously described, the Miyoshi region is not a famous forestry region nor a forest region with a long

Table 1 Number and percentage of households which carried out afforestation, weeding and thimming in 1980 and 1990

\begin{tabular}{|c|c|c|c|c|c|c|c|c|c|c|c|}
\hline & & \multicolumn{2}{|c|}{ Mino } & \multicolumn{2}{|c|}{ Miyoshi } & \multicolumn{2}{|c|}{ Ikeda } & \multicolumn{2}{|c|}{ Yamashiro } & \multicolumn{2}{|c|}{ Ikawa } \\
\hline & & Number & percent. & Number & percent. & Number & percent. & Number & percent. & Number & percent. \\
\hline \multirow[t]{2}{*}{ Number of Households } & 1980 & 952 & 100 & 838 & 100 & 1,815 & 100 & 1,247 & 100 & 751 & 100 \\
\hline & 90 & 521 & 100 & 736 & 100 & 1,517 & 100 & 1,025 & 100 & 684 & 100 \\
\hline \multirow[t]{2}{*}{ Afforestation } & 1980 & 27 & 5 & 106 & 13 & 205 & 11 & 162 & 13 & 117 & 16 \\
\hline & 90 & 20 & 4 & 63 & 9 & 92 & 6 & 39 & 4 & 62 & 9 \\
\hline \multirow[t]{2}{*}{ Weeding } & 1980 & 171 & 29 & 329 & 39 & 818 & 45 & 711 & 57 & 478 & 64 \\
\hline & 90 & 155 & 30 & 249 & 34 & 462 & 30 & 210 & 20 & 277 & 40 \\
\hline \multirow[t]{4}{*}{ Thinning } & 1980 & 32 & 5 & 49 & 6 & 226 & 12 & 248 & 20 & 80 & 11 \\
\hline & 90 & 50 & 10 & 53 & 7 & 176 & 12 & 173 & 17 & 99 & 14 \\
\hline & & \multicolumn{2}{|c|}{ Mikamo } & \multicolumn{2}{|c|}{ Higashi-iyayama } & \multicolumn{2}{|c|}{ Nishi-iyayama } & \multicolumn{2}{|c|}{ Miyoshi region } & \multicolumn{2}{|c|}{ Tokushima pref. } \\
\hline & & Number & percent. & Number & percent. & Number & percent. & Number & percent. & Number & percent. \\
\hline \multirow[t]{2}{*}{ Number of Households } & 1980 & 1,012 & 100 & 670 & 100 & 528 & 100 & 7,453 & 100 & 32,116 & 100 \\
\hline & 90 & 872 & 100 & 509 & 100 & 432 & 100 & 6,296 & 100 & 27,364 & 100 \\
\hline \multirow[t]{2}{*}{ Afforestation } & 1980 & 102 & 10 & 74 & 11 & 59 & 11 & 852 & 11 & 448 & 2 \\
\hline & 90 & 72 & 8 & 4 & 1 & 7 & 2 & 359 & 6 & 1,438 & 5 \\
\hline \multirow[t]{2}{*}{ Weeding } & 1980 & 426 & 42 & 431 & 64 & 306 & 58 & 3,670 & 49 & 1,959 & 7 \\
\hline & 90 & 334 & 38 & 75 & 15 & 76 & 18 & 1,838 & 29 & 6,529 & 24 \\
\hline \multirow[t]{2}{*}{ Thinning } & 1980 & 68 & 7 & 115 & 17 & 40 & 8 & 858 & 12 & 684 & 3 \\
\hline & 90 & 116 & 13 & 82 & 16 & 75 & 17 & 824 & 13 & 2,843 & 10 \\
\hline
\end{tabular}

Source: 1980 and 1990 Census of Forestry 
history. In general, it is a private forest dominated region with maturing forest resources and, therefore, the grade of its logs fall within the ordinary level. With this, no effective domestic timber supply system encompassing production, processing and distribution from upstream to downstream has been established here. Presently, therefore, the up stream-downstream cooperation activities in the forestry and lumber industries do not fulfill their functions. To overcome the keen competition exerted by foreign timber and other domestic timber producing areas, it is necessary to construct the system with the aid of the Forest Information System.

\section{FUTURE VISION OF THE INFORMATION STREAM DESCRIBED IN THE FUNDAMENTAL PLAN}

Table 2 provides a brief history of the activities promoting regional forestry. The Fundamental Plan was agreed and published in March, 1992. The following eight factors indicate the future course described in this plan.

(1) Construction of a general forestry center

(2) Education and reservation of forest workers

(3) Reorganization and intensification of forestry enterprises

(4) Investment in high performance forestry machinery

(5) Consolidation of the forest product processing and distribution system.

(6) Improvement of forests

(7) Achievement of locality-brand forest by-products

(8) Synthetic utilization of forest space

The principle of this plan aims at the establishment of lumber processing estates in Mino Town and in the western part of the region, together with the construction of a general forestry center, the reorganization and intensification of logging contractors as forest owners' cooperatives in this region as the hardware-based policy, and the establishment of an F.I.S. as the software-based policy.

The General Forestry Center should provide five functions:

1) Promotion of forestry

2) Exhibition and sale of forest products

3) Instruction and education in the form of seminars
4) Forestry information center

5) Tourist information

With the office of the River Basin Forestry Vitalization Center located in this building, the Center should generally regulate subjects related to forests and forestry as well as serve as a timber information dissemination center. Toward establishing the domestic timber supply system, a domestic timber distribution/processing base with a log market, sawmills and other related facilities is now under construction in Mino town, with another in the planning stages.

This base should collect a wide range of information related to timber distribution, processing and sales. However, intensification will be attained in more upstream areas in the region through the introduction of high performance forestry machinery to the forestry enterprises. Due to an adequate distribution of their machinery and work force, these forestry enterprises should collect and utilize as much information related to their area as possible. The most important factor is, therefore, to effectively integrate and adjust this information.

\section{SUBJECT TO THE ESTABLISHMENT OF A NETWORKED INFORMATION SYSTEM}

As stated, in the Miyoshi region, preparations of the hardware required for domestic timber supply and forest management is now in progress. However, while preparations for the software, in this case a networked information system, is underway, certain problems are being encountered. Therefore, the information system is aimed at the following four points;

(1) Information exchange and sending: As much as possible, information should be exchanged between the inner members of the system. With this, the promotion of electrification should also be considered to enable such information exchange.

(2) Marketing: Not only the normal form of forestry information should be collected, but information related to marketing should also be obtained, such as the diameters of the timber which will be produced in the region. Forest enterprises such as the forest owners' cooperatives would obtain information related to the present

Table 2 Progress of activities for promoting river basin forest management system

$\begin{array}{ll}\text { Sep. } 1991 & \begin{array}{l}\text { Establishment of the River Basin Forestry Vitalization Center and the River Basin Forestry Vitalization } \\ \text { Council }\end{array} \\ \text { Dec. } 1991 & \text { Establishment of Sectional Meeting for improvement of log distribution } \\ \text { Apr. 1992 } & \text { Establishment of Sectional Meeting for introducing high performance forestry machinery } \\ \text { July 1994 } & \text { Establishment of Sectional Meeting for improvement of forest labor force } \\ \text { July 1995 } & \text { The General Forestry Center was completed }\end{array}$

Source: Materials offered by the office of the River Basin Forestry Vitalization Center 
true state of their forest resources and intentions of the forest owners. With this, information regarding demands is also collected at the timber processing estate. By considering this information synthetically, the system is enabled to function in the most suitable manner and provide effective results.

(3) Connection between various industries: as business opportunities are to be found almost everywhere, connection to various industries and people becomes highly valuable factor.

(4) Efficient management - cost down: the networked information system enables effective cost-down. As a first step, an information center is planned to be located in the General Forestry Center in Yamashiro in the southern part of this region. To conduct efficient forest management such as producing thinning schedules, road planning and logging operations, the development of GIS-based system is now in progress.

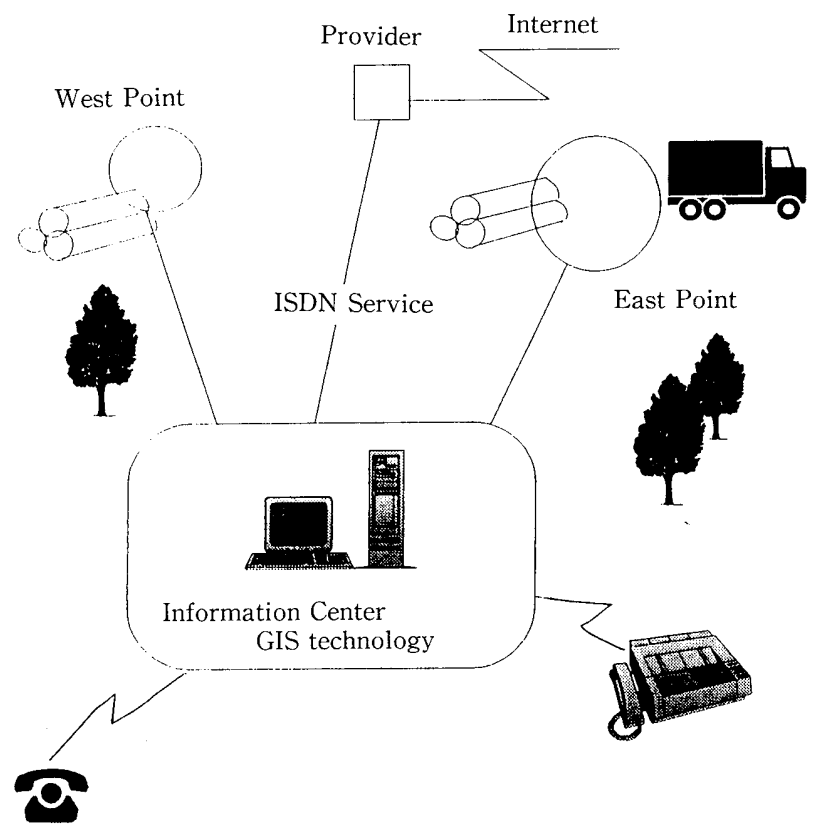

Fig. 2 Network system
From the standpoint of these four factors, the network system shown in Fig. 2 would be very suitable for the Miyoshi region. As the hub, the Center is located in Yamashiro Town because forestry activities are fairly intense there. As the second hub of this region, a Forestry Machinery Center is planned in the timber processing estate in Mino Town in the eastern part, with another estate in the western part. A distributed processing network between these hubs via an ISDN service is, therefore, made available. The forest sectors are also connected to the information center via public network. As a connection to a wide area network, the Internet service may be a viable solution.

Certain investment in hardware and payment to persons to operate the system are inevitable. Also, as the information system is improved, the cost required for its operation will increase accordingly. In this region, the forestry section does not have the financial foundation required for such an enterprise although it would be very advantageous for such a region to establish and maintain a relatively compact information system such as that described herein.

\section{LITERATURE CITED}

Amano,M.,(1986): Computerization for Regional Forest Management*. Shinrinkumiai 191:4-7(in Japanese)

Ando, Y., (1986): For the Formation of Information System in Wood Trading*. Shinrinkumiai 192:4-7(in Japanese)

Ando, Y.,(1991): The Proceeding and the Destination of TimberVAN*. Sanrin 1282:28-36 (in Japanese)

Kato, S., (1991): Current Situations of the Information-oriented Movements in Timber Industries. J. For. Econ. 119:76-83 (in Japanese)

Kato, S., (1994): The present condition and subject of forest information system. J. For. Econ. 125:118-122 (in Japanese)

Kawamura, M.,(1995): " Basin Forestry " Policy and The Problem of Forest Owners Cooperatives. Forest Economy 562:22-30(in Japanese)

Mochida, H., (1994): On characteristics of river basin control system and its point of issue. J. For. Mechan. Soc. 493:2-9 (in Japanese)

* The titles are tentative translations from original Japanese titles by the authors of this paper.

(Received 28 November 1995)

(Accepted 19 Jannary 1996) 